\title{
Zorro Sacro
}

\section{Sacral Fox}

\section{William Andrés Prada Mancilla1®}

${ }^{1}$ Universidad de la Sabana, Clínica de la Sabana, Bogotá, Colombia Rev Argent Radiol 2022;85(Suppl S1):S17.

Se trata de un paciente adulto joven que consulta por dolor lumbar mecánico recurrente con estudios de radiografía y tomografía normales. El servicio tratante de neurología solicita resonancia magnética (RM) para evaluación específica de articulación sacroilíaca. En la valoración multimodal de la articulación sacroilíaca no se evidencian alteraciones inflamatorias.

En la - Figura 1 se muestra una RM de pelvis con información ponderada en $\mathrm{T} 2$ de un corte coronal que evidencia la cara de un zorro. Las orejas son ambos huesos ilíacos y se identifica la interfase con la cara del zorro, la cual pertenece a la articulación sacroilíaca que, por su corte, se demuestra la porción posterior sindesmótica de la articulación sacroilíaca. La imagen de la cara del zorro corresponde al cuerpo del sacro. Los ojos del zorro

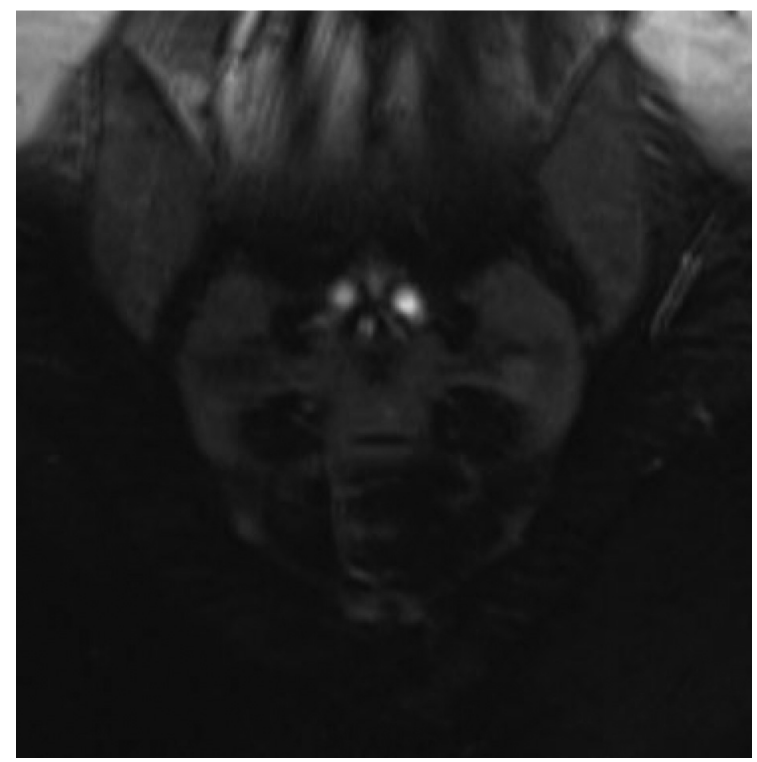

Fig. 1 Imagen de RM de pelvis en corte coronal con información ponderada en T2.

received

May 2, 2020

accepted

August 25, 2020

published online

March 29, 2021
Address for correspondence William Andrés Prada Mancilla, MsC, Universidad de la Sabana, Clínica de la Sabana, Bogotá, Colombia (e-mail: wpradamancilla@gmail.com).

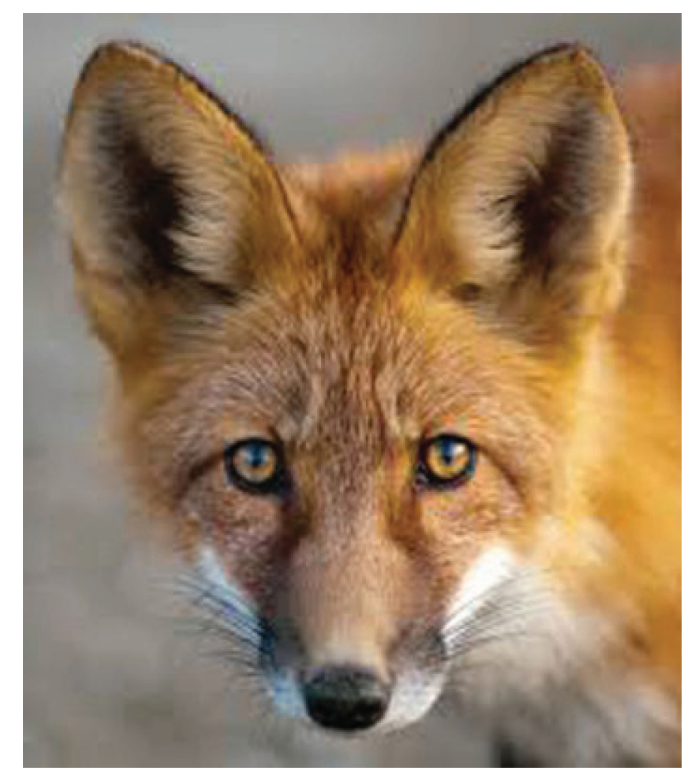

Fig. 2 Zorro. Tomada de https://www.flickr.com/photos/ 57557144@N06/5302090111.

están representados por los primeros agujeros sacros dorsales. La nariz se encuentra insinuada por los tubérculos de las apófisis transversas. La porción medial superior de la frente del zorro está representada por un volumen parcial del canal raquídeo con presencia de líquido cefalorraquídeo, el cual presenta intensidad de señal alta en las imágenes con información ponderada en T2.

En la - Figura 2 se muestra la imagen de la cara de un zorro para la correlación con la imagen de RM.

\section{Conflicto de Intereses}

Los autores declaran no tener ningún conflicto de intereses.
(C) 2021. Sociedad Argentina de Radiología. All rights reserved. This is an open access article published by Thieme under the terms of the Creative Commons Attribution-NonDerivative-NonCommercial-License, permitting copying and reproduction so long as the original work is given appropriate credit. Contents may not be used for commercial purposes, or adapted, remixed, transformed or built upon. (https://creativecommons.org/ licenses/by-nc-nd/4.0/)

Thieme Revinter Publicações Ltda., Rua do Matoso 170, Rio de Janeiro, RJ, CEP 20270-135, Brazil 